Eur J Clin Chem Clin Biochem

1995; 33:715-719

(c) 1995 Walter de Gruyter \& Co.

Berlin · New York

\title{
Validation of Red Cell Sodium-Lithium Countertransport Measurement - Influence of Different Loading Conditions
}

\author{
By Wilfried Besch ${ }^{1}$, Doreen Schläger ${ }^{1}$, Jesper Brahm ${ }^{2}$ and Klaus-Dieter Kohnert ${ }^{1}$ \\ ${ }^{1}$ Institut für Diabetes „Gerhardt Katsch“ der Ernst-Moritz-Arndt-Universität Greifswald, Karlsburg, Germany \\ 2 Department of Medical Physiology, The Panum Institute, University of Copenhagen, Denmark
}

(Received April 6/June 6, 1995)

Summary: Increased sodium-lithium countertransport in erythrocytes from patients with long-standing type I (insulin-dependent) diabetes mellitus has been considered as an early marker of nephropathy. Since the activity and kinetics of the sodium-lithium countertransport may critically depend on loading conditions, this study was aimed at determining sodium-lithium countertransport activity, Michaelis constant $K_{\mathrm{m}}$ and maximum velocity $V_{\max }$ in erythrocytes loaded in two different $\mathrm{Li}^{+}$solutions. Sodium-lithium countertransport activity was determined in erythrocytes in 8 healthy control subjects after loading with $150 \mathrm{mmol} / \mathrm{l} \mathrm{LiCl}$ compared with those loaded with 150 $\mathrm{mmol} / 1 \mathrm{LiHCO}_{3}$. Sodium-lithium countertransport activity was similar for both loading procedures, although the erythrocyte lithium content did significantly differ (mean $\pm \mathrm{SEM}, 7.0 \pm 0.5$ for $\mathrm{LiCl}$ and $8.9 \pm 0.5 \mathrm{mmol} / 1$ of cells for $150 \mathrm{mmol} / 1 \mathrm{LiHCO}_{3}$ ). There were no significant changes in the $K_{\mathrm{m}}$ and $V_{\max }$. Increase of osmolality in efflux media containing 200 and $250 \mathrm{mmol} / 1 \mathrm{NaCl}$ resulted in a negligible shrinking of the red blood cells, not exceeding $2.2 \%$.

The main advantage is the short loading time of $15 \mathrm{~min}$ for $\mathrm{LiHCO}_{3}$ compared with 3 hours for $\mathrm{LiCl}$. Under these conditions saturating intracellular $\mathrm{Li}^{+}$concentrations can be obtained much more rapidly than with $\mathrm{LiCl}$ loading, thereby minimising alterations of the cell membranes. $\mathrm{LiHCO}_{3}$ loading shortens the experimental time considerably and enables a greater number of samples to be screened from larger population cohorts.

\section{Introduction}

There have been several reports of increased sodiumlithium countertransport (SLC) in patients with essential hypertension $(1,2)$ and insulin-dependent diabetes with and without microalbuminuria $(3-5)$. This sodium-lithium countertransport system exchanges $\mathrm{Li}^{+}$for $\mathrm{Na}^{+}$in an external $\mathrm{Na}^{+}$-stimulated $\mathrm{Li}^{+}$efflux, and it shows saturation according to Michaelis-Menten kinetics (6). An elevated sodium-lithium countertransport activity in erythrocytes has been found in hypertensive subpopulations (1) and in patients with insulin-dependent diabetes mellitus complicated by renal disease $(7,8)$, but not in individuals with secondary cause of hypertension (9). In contrast, Rutherford et al. have reported (10) that the elevated sodium-lithium countertransport activity in patients with essential hypertension is attributable to a low
$K_{\mathrm{m}}$ with no difference in $V_{\max }$, as compared with normotensive subjects. Possibly, these discrepancies may partly be due to different assay methodologies or to selection bias.

Thus, the aim of this study was to validate the sodiumlithium countertransport measurements and to assess the influence of different loading media on the countertransport activity and its kinetics.

\section{Materials and Methods}

Preparation of red cell suspension

Venous blood from 8 non-fasted healthy volunteers (age: $25 \pm 4$ years, mean \pm SD) was collected between 7.00-8.00 a.m., using Monovette ${ }^{\circledR}$ syringes (Sarstedt, Nümbrecht, Germany) containing EDTA, and centrifuged at $1500 \mathrm{~g}$. The red cells were washed four 
times with an isoosmotic washing büffer $(75 \mathrm{mmol} / \mathrm{l}$ magnesium chloride $/ 80 \mathrm{mmol} / 1$ sucrose $/ 5 \mathrm{mmol} / 1$ glucose $/ 10 \mathrm{mmol} / 1$ tris(hydroxymethyl)aminomethane-morpholino-propane sulphonic acid [Tris-MOPS], $\mathrm{pH} \mathrm{7.55)}$ at $20^{\circ} \mathrm{C}$. Osmolality was measured using a Knauer automatic semi-micro osmometer A300. Red cell suspensions were kept at room temperature and used within one hour.

\section{Sodium-lithium countertransport activity - comparison of methods}

Measurement of sodium-lithium countertransport after loading with lithium chloride

The method used was similar to that described by Canessa et al. (1). Four millilitres of washed red cells were incubated for three hours at $37^{\circ} \mathrm{C}$ with shaking in $20 \mathrm{ml}$ loading solution $(150 \mathrm{mmol} / \mathrm{l}$ lithium chloride/10 mmol/1 glucose $/ 10 \mathrm{mmol} / 1$ Tris-MOPS, $\mathrm{pH}$ 7.55). The cells were washed five times with washing buffer to remove the extracellular lithium. An aliquot of the lithium-loaded cells was taken for determination of haematocrit, haemoglobin and the lithium content of the haemolysed cells by atomic absorption spectrometry (UNICAM Model Solaar 939). The lithium efflux was measured by incubating $1.8 \mathrm{ml}$ of cell suspension (haematocrit $0.05-0.08)$ in a sodium-free medium and in a sodium medium as described in detail (11). After 0, 30, 60 and 90 minutes, incubation in either medium was stopped by cooling the tubes on ice for two minutes and subsequent centrifugation at $1500 \mathrm{~g}$ for four minutes at $4{ }^{\circ} \mathrm{C}$. Lithium concentration in the supernatant was measured by atomic absorption spectrophotometry. Sodium-lithium countertransport activity was determined as the difference between the sodium-stimulated lithium efflux and the passive efflux in potassium chloride medium over time.

The intra-assay variation of our assay is $7.7 \%(n=9)$ and the interassay variation is $15.3 \%(n=4)$, where the inter-assay variation expresses both the variability of the test and the biological variability by measuring 4 samples during a four week period in five individuals. These assay variations are comparable to those reported in the literature $(3,5)$.

\section{Measurement of sodium-lithium countertransport after loading with lithium bicarbonate}

This method was carried out by the same procedure as described above except for the loading conditions. Instead of a lithium chloride solution, the erythrocytes were incubated in a lithium bicarbonate medium $(150 \mathrm{mmol} / \mathrm{l}$ lithium bicarbonate $/ 10 \mathrm{mmol} / \mathrm{h} \mathrm{glu-}$ cose $/ 10 \mathrm{mmol} / \mathrm{l}$ Tris-MOPS gassed with $\mathrm{CO}_{2}$ until the $\mathrm{pH}$ value had adjusted to 7.55) according to Ibsen et al. (12) for $15 \mathrm{~min}$. Thereafter the cells were washed five times and the efflux measurements were performed as mentioned above. Sodium-lithium countertransport values obtained with both methods were compared in 8 healthy subjects.

\section{$K_{m}$ and $V_{\max }$ of sodium-lithium countertransport}

Erythrocytes were loaded with $150 \mathrm{mmol} / \mathrm{l}$ lithium chloride or 150 $\mathrm{mmol} / \mathrm{l}$ lithium bicarbonate. The erythrocytes were then incubated in media containing $0,50,100,150,200$ and $250 \mathrm{mmol} / \mathrm{l} \mathrm{NaCl}$, respectively. The media also contained $1 \mathrm{mmol} / / \mathrm{MgCl}_{2} / 10 \mathrm{mmol} / \mathrm{l}$ glucose $/ 0.1 \mathrm{mmol} / 1$ ouabain $/ 10 \mathrm{mmol} / /$ Tris-MOPS, $\mathrm{pH}$ 7.55. The solutions containing $\leqslant 100 \mathrm{mmol} / \mathrm{l} \mathrm{NaCl}$ were made isotonic with potassium chloride according to Ibsen et al. (12) who found identical values for leak efflux in $\mathrm{KCl}$ medium and in media used in other laboratories such as cholinium chloride or magnesium chloride.

The Michaelis constant $K_{\mathrm{m}}$ and maximum velocity $V_{\max }$ were calculated by non-linear regression of the Michaelis-Menten equation $v=V_{\max }[\mathrm{S}] /\left(K_{\mathrm{m}}+[\mathrm{S}]\right)$ using the Marquardt-Levenberg algorithm (see Statistical analysis). The kinetic constants $K_{\mathrm{m}}$ and $V_{\max }$ of sodium-lithium countertransport activity were determined in erythro- cytes from 8 normal healthy subjects at the different $\mathrm{Li}^{+}$loadings with $150 \mathrm{mmol} / \mathrm{l}$ lithium chloride or $150 \mathrm{mmol} / \mathrm{l}$ lithium bicarbonate. The intra-assay variation for $K_{\mathrm{m}}$ was $13.5 \%(\mathrm{n}=16)$ and for $V_{\max } 6.3 \%(\mathrm{n}=16)$.

\section{Cell volume measurements.,}

Volume measurements were carried out with a cell counter CASY ${ }^{\circledR}$ (Schärfe System GmbH, Reutlingen, Germany). Erythrocyte suspensions were diluted to a final concentration of $30 \times 10^{6} / 1$. The electronic pulse areas related to the particle passage through a $60 \mu \mathrm{m}$ diameter capillary tube were analysed. Mean red cell volume was calculated from the size distribution curve between 4.0 and $6.0 \mu \mathrm{m}$ cell diameter. Triplicate measurements were performed in $0.04 \mathrm{~mol} / \mathrm{h}$ phosphate/saline buffer, $\mathrm{pH} 7.4$ at room temperature.

\section{Statistical analysis}

Results with a normal distribution are expressed as mean \pm SD. The normality was tested by the Kolmogorov-Smirnov test. The significance of differences between two groups was assayed using the Student's t-test. P values (two-tailed) $<0.05$ were considered statistically significant. Non-linear fitting of the Michaelis-Menten curve was performed by the computer software "SigmaPlot for Windows" (Jandel Scientific GmbH, Erkrath, Germany). Non-linear curve fit uses the Marquardt-Levenberg algorithm to find the coefficients $K_{\mathrm{m}}$ and $V_{\max }$. This algorithm seeks the values of parameters that minimize the sum of the squared differences between the values of the observed and predicted values of the dependent variable.

\section{Results}

The relationship between sodium-lithium countertransport activity and external sodium concentration for the calculation of the Michaelis constant and maximum velocity are shown in figure 1 . The kinetics of $\mathrm{Li}^{+}$efflux from erythrocytes of all healthy subjects studied, obtained with the two loading procedures, are demon-

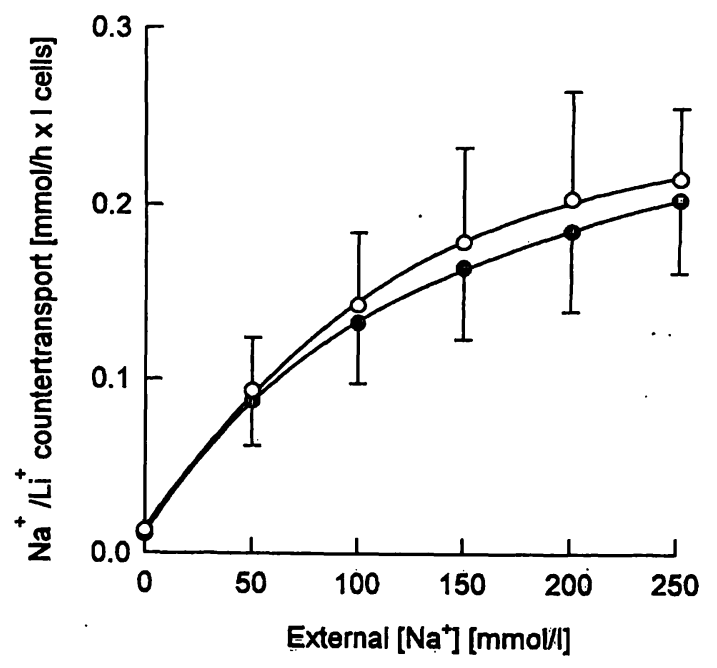

Fig. 1 Relationship between sodium-lithium countertransport activity ${ }_{n}$ and external sodium concentration of red blood cells after loading with $150 \mathrm{mmol} / \mathrm{LiCl}(0)$ or $150 \mathrm{mmol} / / \mathrm{LiHCO}_{3}(\bullet)$. The kinetic experiments were run in duplicate, and each data point represents the mean $\pm S D$ of 8 individúl blood samples. 
strated in table 1. Sodium-lithium countertransport activity did not significantly differ between both loading procedures. Also, both the Michaelis constant and the maximum velocity were the same in erythrocytes loaded with lithium chloride or with lithium bicarbonate. Table 1 further shows that the intracellular $\mathrm{Li}^{+}$content significantly increased when lithium chloride was replaced by lithium bicarbonate. Osmolalities in the efflux media containing 200 and $250 \mathrm{mmol} / 1 \mathrm{NaCl}$ (tab. 2) were somewhat higher than in the other solutions. However, as shown in table 2 , increase of the osmolality in those solutions resulted in a negligible shrinking of erythrocytes, not exceeding $2.2 \%$.

Loading of the erythrocytes in $\mathrm{LiHCO}_{3}$ was much faster than in $\mathrm{LiCl}$ medium, so that the intracellular $\mathrm{Li}^{+}$concentrations given in table 1 were attained within $15 \mathrm{~min}$,

Tab. 1 Influence on erythrocyte sodium-lithium countertransport kinetics of different counteranions in $\mathrm{Li}^{+}$-loading medium. Eight normal healthy subjects were used for sodium-lithium countertransport measurements (mean $\pm S D$ ).

\begin{tabular}{|c|c|c|}
\hline & $\begin{array}{l}\mathrm{LiCl} \\
150 \mathrm{mmol} / \mathrm{l}\end{array}$ & $\begin{array}{l}\mathrm{LiHCO}_{3} \\
150 \mathrm{mmol} / 1\end{array}$ \\
\hline $\begin{array}{l}\text { Sodium-lithium } \\
\text { countertransport activity } \\
{[\mathrm{mmol} / \mathrm{h} \times 1 \text { cells }]}\end{array}$ & $0.168 \pm 0.062$ & $0.165 \pm 0.067$ \\
\hline$V_{\max }$ & $0.336 \pm 0.089$ & $0.299 \pm 0.070$ \\
\hline$K_{\mathrm{m}}[\mathrm{mmol} / /]$ & $136 \pm 27$ & $127 \pm 40$ \\
\hline $\begin{array}{l}\mathrm{Li}^{+} \text {content } \\
{[\mathrm{mmol} / 1 \text { cells }]}\end{array}$ & $7.0 \pm 1.4^{1}$ & $8.9 \pm 1.5$ \\
\hline
\end{tabular}

${ }^{1} \mathrm{p}<0.05$ vs. lithium bicarbonate

Tab. 2 Cell volume and osmolality of the erythrocytes in different media.

\begin{tabular}{llll}
\hline $\begin{array}{l}\text { Media } \\
(\mathrm{mmol} / \mathrm{l})\end{array}$ & $\begin{array}{l}\text { Cell } \\
\text { volume }\end{array}$ & $\begin{array}{l}\text { Change } \\
\text { of mean } \\
\text { volume }\end{array}$ & Osmolality \\
{$\left[\mu \mathrm{m}^{3}\right]$} & {$[\mathrm{mmol} / \mathrm{kg}]$} \\
\hline Loading media & & & \\
$\mathrm{LiCl}(150)$ & 64.5 & 0.1 & 295 \\
$\mathrm{LiHCO}(150)$ & 64.8 & 0.2 & 295 \\
& & & \\
Efflux media & & & \\
$\mathrm{KCl}(150)$ & 64.7 & 0.1 & 295 \\
$\mathrm{NaCl}(50)+\mathrm{KCl} \mathrm{(100)}$ & 64.8 & 0.2 & 295 \\
$\mathrm{NaCl}(100)+\mathrm{KCl}(50)$ & 64.6 & 0 & 295 \\
$\mathrm{NaCl}(150)$ & 64.6 & 0 & 295 \\
$\mathrm{NaCl}(200)$ & 63.6 & 1.0 & 400 \\
$\mathrm{NaCl}(250)$ & 63.2 & 1.4 & 510 \\
\hline
\end{tabular}

\footnotetext{
1 Results obtained with two different samples

2 Referred to erythrocyte volume in isotonic $150 \mathrm{mmol} / 1 \mathrm{NaCl} \mathrm{me}-$ dium
}

compared with 180 min with the $\mathrm{LiCl}$ method (fig. 2). The increase of $\mathrm{Li}^{+}$concentration in red cells was nearly linear with time. Thus, saturation was not achieved under these conditions. The rates of both $\mathrm{Na}^{+}$-induced $\mathrm{Li}^{+}$ efflux (release into $\mathrm{NaCl}$ ) and the spontaneous $\mathrm{Na}^{+}$-independent release (release into $\mathrm{KCl}$ ) were nearly equal after loading the erythrocytes in lithium bicarbonate or lithium chloride medium. The values for sodium-lithium countertransport activity, maximum velocity and $\mathrm{Mi}$ chaelis constant were not significantly influenced by the method used for their determination $(p>0.1)$, as demonstrated by the straight lines in figure 3 .

\section{Discussion}

Discrepant findings have been reported in the literature with respect to the maximal activity and kinetic constants $K_{\mathrm{m}}$ and $V_{\max }$ of the erythrocyte sodium-lithium countertransport activity (9). This might be explained by either the metabolic status of the patients investigated, different assay methodologies or the use of an insufficiently high sodium concentration for their correct determination. Canessa et al. (9) have recently emphasized the importance of achieving sufficiently high intracellular $\mathrm{Li}^{+}$concentrations in order to ensure accurate measurement of sodium-lithium countertransport activity. Duhm \& Becker (6) investigated the $\mathrm{Na}^{+}$-dependent $\mathrm{Li}^{+}$ transport across the human red cell membrane. Moreover, the mechanisms that lead to increased sodium-lithium countertransport activity in various disease conditions seem to be different, e.g. in hypertension the $K_{m}$ is low, whereas in type I diabetes $V_{\max }$ is increased (10, 13). It is now clear that there are no significant differences in the maximal sodium-lithium countertransport

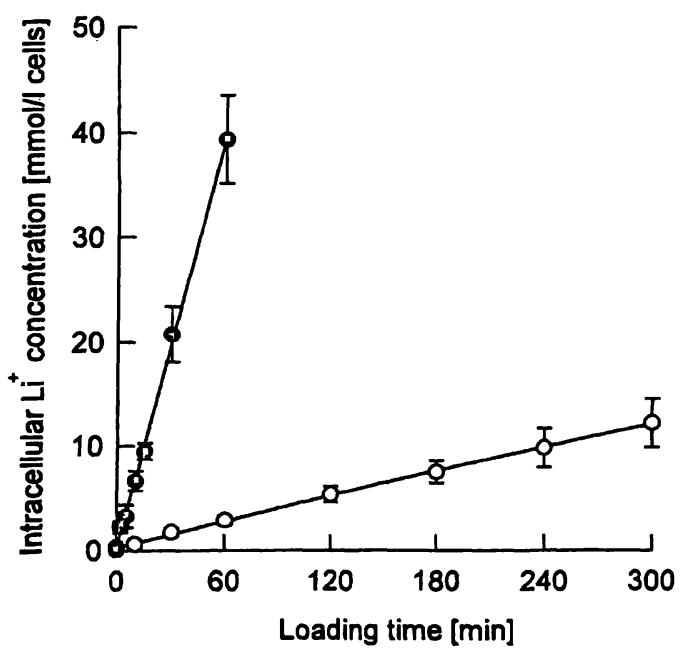

Fig. 2 Effect of the loading procedure on the time dependence of $\mathrm{Li}^{+}$concentration in human erythrocytes. Loading was performed with $150 \mathrm{mmol} / 1 \mathrm{LiCl} \mathrm{(0)}$ and $150 \mathrm{mmol} / / \mathrm{LiHCO}_{3}(\odot)$ at $37^{\circ} \mathrm{C}$. Each data point represents the mean \pm SD of 5 individual blood samples. 


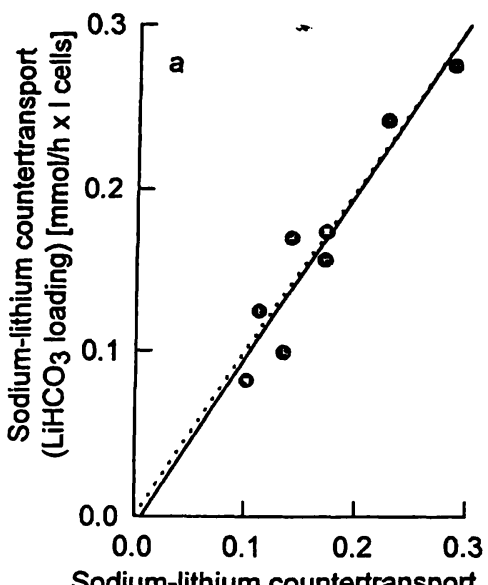

Sodium-lithium countertransport ( $\mathrm{LiCl}$ loading) [mmol/h $\times$ I cells]
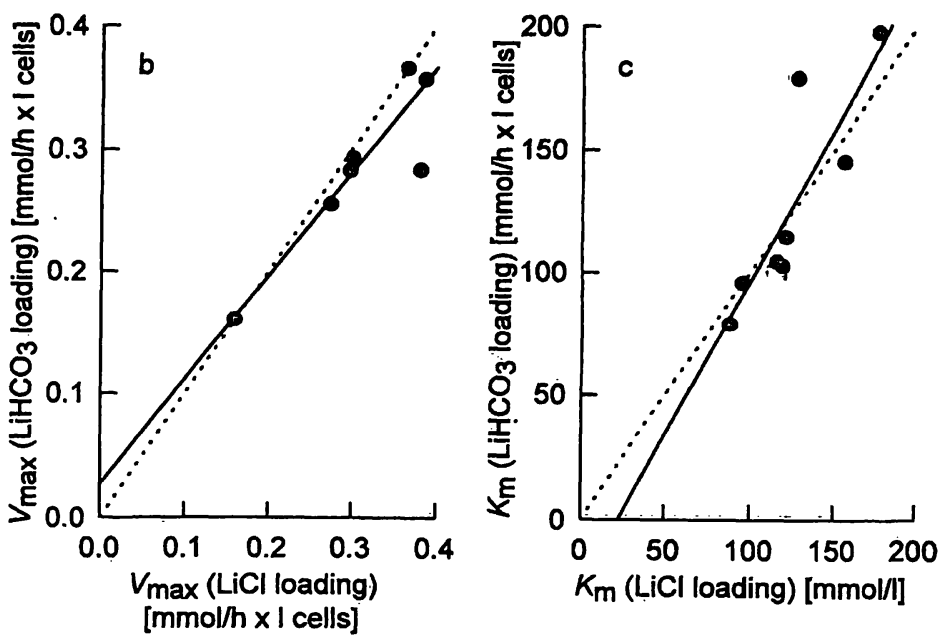

Fig. 3 Comparison of

a) sodium-lithium countertransport activity

b) maximum velocity $\left(V_{\max }\right)$ and

c) Michaelis constant $\left(K_{\mathrm{m}}\right)$

of erythrocytes from 8 normal subjects after loading with either $150 \mathrm{mmol} / 1$ lithium bicarbonate ( $y$-axis) or lithium chloride ( $x$ axis). The equations of the regression lines (solid lines) are

a) $y=1.02 x-0.007 ; r=0.948$
b) $y=0.84 x-0.027 ; r=0.915$
c) $y=1.24 x-28.0 ; \quad r=0.859$

The dotted lines represent the identity of both methods. activity after loading the erythrocytes in either $\mathrm{LiCl}$ or $\mathrm{LiHCO}_{3}$, indicating that intracellular $\mathrm{Li}^{+}$concentrations above $5 \mathrm{mmol} / \mathrm{l}$ allow precise $\mathrm{Li}^{+}$efflux measurements. It therefore seems unlikely that $\mathrm{Li}^{+}$loading with lithium bicarbonate would affect the sodium-lithium countertransport activity data reported in non-nephropathic and nephropathic diabetes by Elving et al. (3) or Jensen et al. (4). In previous studies, employing the well-characterised $\mathrm{LiCl}$ method, we found no significant differences in the erythrocyte sodium-lithium countertransport activity between subgroups of normoalbuminuric and microalbuminuric type I diabetic patients (11), although their activity was higher than in agematched healthy control subjects. In this respect, our previous results compare well with those of Elving et al. (3) and Jensen et al. (4).

From the present results we may conclude that $\mathrm{LiHCO}_{3}$ loading of erythrocytes results in a reliable and convenient method for measuring the sodium-lithium countertransport activity of erythrocytes. The main advantage is that under these conditions high intracellular $\mathrm{Li}^{+}$concentrations can be obtained, and much more rapidly than with $\mathrm{LiCl}$ loading, thereby minimising alterations of the cell membranes that may occur during lengthy incubations. Since the loading capacity of the erythrocytes is high in the presence of $\mathrm{LiHCO}_{3}$, the loading time ought to be carefully controlled and strictly limited. $\mathrm{LiHCO}_{3}$ loading considerably shortens the time needed for an experiment and enables a greater number of samples to be screened from larger population cohorts. With respect to the various mechanisms that induce changes of sodium-lithium countertransport activity in different disease states, it should be emphasised that determination of $K_{\mathrm{m}}$ and $V_{\max }$ requires carefully standardised loading conditions. The present loading procedure rapidly achieves $\mathrm{Li}^{+}$contents of more than $10 \mathrm{mmol} / \mathrm{l}$ red cells (see fig. 2) and circumvents the use of nystatin (9), a polyene antibiotic that possibly disrupts the internal electrolyte milieu and causes membrane damage $(14,15)$.

\section{Acknowledgements}

This work was supported by the project No. $018293 / \mathrm{M}$ of the "Koordinations- und Aufbauinitiative des Wissenschaftler-Integrations-Programms (KAI-WIP) der Bundesregierung für die neuen Bundesländer der Bundesrepublik Deutschland" and by the grant of the Bundesministerium für Bildung, Forschung und Technologie der Bundesrepublik Deutschland, project No. 07NBL02/D7.

We are grateful to Mrs. Edeltraut Schallock and Mrs. Elke Plewka for their skilful technical assistance.

\section{References}

1. Canessa M, Adragna N, Solomon HS, Connolly TM, Tosteson DC. Increased sodium-lithium countertransport in red cells of patients with essential hypertension. N Engl J Med 1980; 302:772-6.

2. Carr SJ, Thomas TH, Wilkinson R. Erythrocyte sodium-lithium countertransport in primary and renal hypertension: relation to family history. Eur J Clin Invest 1989; 9:101-6. 
3. Elving LD, Wetzels JFM, De Pont JHHM, Berden JHM. Is increased erythrocyte sodium-lithium countertransport a useful marker for diabetic nephropathy? Kidney Int 1992; 41:86271.

4. Jensen JS, Mathiesen ER, Norgaard K, Hommel E, BorchJohnson K, Funder J, et al. Increased blood pressure and erythrocyte sodium/lithium countertransport activity are not inherited in diabetic nephropathy. Diabetologia 1990; 33:619-24.

5. Gall MA, Rossing $P$, Jensen JS, Funder J, Parving HH. Red cell $\mathrm{Na}^{+} / \mathrm{Li}^{+}$countertransport in non-insulin-dependent diabetics with diabetic nephropathy. Kidney Int 1991; 39:135-40.

6. Duhm J, Becker BF. Studies on the lithium transport across the red cell membranes. IV. interindividual variations in the $\mathrm{Na}^{+}$-dependent $\mathrm{Li}^{+}$countertransport system of human erythrocytes. Pflügers Arch 1977; 370:211-9.

7. Krolewski AS, Canessa M, Warram JH, Laffei LMB Christlieb AR, Knowler WC, et al. Predisposition to hypertension and susceptibility to renal disease in insulin-dependent diabetes mellitus. N Engl J Med 1988; 318:140-5.

8. Mangili R, Bending JJ, Scott G, Li LK, Gupta A, Viberti G. Increased sodium-lithium countertransport activity in red cells of patients with insulin-dependent diabetes and nephropathy. N Engl J Med 1988; 318:146-50.

9. Canessa M, Zerbini G, Laffel LMB. Sodium activation kinetics of red blood cell $\mathrm{Na}^{+} / \mathrm{Li}^{+}$countertransport in diabetes: methodology and controversy. J Am Soc Nephrol 1992; 3:S41-9.

10. Rutherford PA, Thomas TH, Wilkinson R. Increased erythrocyte sodium-lithium countertransport activity in essential hy- pertension is due to an increased affinity for extracellular sodium. Clin Sci 1990; 79:365-9.

11. Besch W, Blücher H, Bettin D, Wolf E, Michaelis D, Kohnert $\mathrm{KD}$. Erythrocyte sodium-lithium countertransport, adenosine triphosphatase activity and sodium-potassium fluxes in insulindependent diabetes. Int J Clin Lab Res 1995; 25:104-9.

12. Ibsen KK, Jensen HÆ, Wieth JO, Funder J. Essential hypertension: sodium-lithium countertransport in erythrocytes from patients and from children having one hypertensive parent. Hypertension 1982; 4:703-9.

13. Rutherford PA, Thomas TH, Carr SJ, Taylor R, Wilkinson R. Kinetics of sodium-lithium countertransport activity in patients with uncomplicated type I diabetes. Clin Sci 1992; 82:291-9.

14. Gimsa J, Schnelle T, Zechel G, Glaser R. Dielectric spectroscopy of human erythrocytes: investigations under the influence of nystatin. Biophys J 1994; 66:1244-53.

15. Brezis M, Rosen S, Silva P, Spokes K, Epstein FH. Polyene toxicity in renal medulla: injury mediated by transport activity. Science $1984 ; 224: 66-8$.

Dr. Wilfried Besch

FG Experimentelle Endokrinologie

Institut für Diabetes „Gerhardt Katsch“ der Ernst-Moritz-Arndt-Universität Greifswald Greifswalder Straße 11a

D-17495 Karlsburg Germany 
